\title{
EFFECT OF HOLDING TIME ON THE BACTERIAL LOAD OF SURGICAL INSTRUMENTS
}

\author{
S. T. Mohite1, Mahesh Reddy S², Ashok Y. Kshirsagar³, Madhavendra Kabra ${ }^{4}$, Basavaraj Nagur 5 , Sangeeta Biradar6, Shruti Panicker ${ }^{7}$, \\ Aditya Phadke 8
}

${ }_{1}$ Professor, Department of Microbiology, Krishna Institute of Medical Sciences and Research.

${ }^{2}$ Resident, Department of Surgery, Krishna Institute of Medical Sciences and Research.

3 Professor, Department of Surgery, Krishna Institute of Medical Sciences and Research.

${ }^{4}$ Resident, Department of Surgery, Krishna Institute of Medical Sciences and Research.

${ }^{5}$ Resident, Department of Surgery, Krishna Institute of Medical Sciences and Research.

${ }^{6}$ Resident, Department of Surgery, Krishna Institute of Medical Sciences and Research.

${ }^{7}$ Resident, Department of Surgery, Krishna Institute of Medical Sciences and Research.

${ }^{8}$ Resident, Department of Surgery, Krishna Institute of Medical Sciences and Research.

\section{ABSTRACT}

The aim of this investigation was to determine the bacterial load on used instruments and to evaluate the relationship between the bacterial load and holding time prior to cleaning. Forty six sets were evaluated to establish the average number of bacteria per square centimeter. For the experimental study, three different bacteria were prepared in sheep blood and used to contaminate sterile stainless steel pieces with surface area of $10 \mathrm{~cm}^{2}$. After incubation at room temperature for $2,4,6,8,12,24,36$ and $48 \mathrm{~h}$, colonies were counted as compared to time zero. Bacterial counts were between 20 and $320 \mathrm{CFU} / \mathrm{cm} 2$, depending on the operation site. Bacterial load was found to have increased after $6 \mathrm{hrs}$. An increase of $3 \log _{10} \mathrm{CFU} / \mathrm{cm} 2$ was measured after $12 \mathrm{~h}$. It is imperative to clean surgical instruments in the first $6 \mathrm{~h}$ to ensure effective disinfection and sterility.

\section{KEYWORDS}

Surgical Instruments, Bacterial Load, Bioburden, Holding Time, Contamination.

HOW TO CITE THIS ARTICLE: Mohite ST, Mahesh Reddy S, Kshirsagar AY, et al. Effect of holding time on the bacterial load of surgical instruments. J. Evolution Med. Dent. Sci. 2016;5(16):763-765, DOI: 10.14260/jemds/2016/177

\section{INTRODUCTION}

All surgical instruments are contaminated with microorganisms after a particular interval of time before sterilization. This bacterial load depends on the site of operation. Earlier studies have shown that cleaning is critical in removing the gross debris, preventing cross contamination, protecting the health care workers and maintaining the medical instruments. The number of bacteria contaminating medical devices will determine how long it will take for a cleaning agent or disinfectant to destroy them. This is due to the genetically heterogeneous bacterial populations.[1] Very few data provide accurate estimates of the levels and types of contamination on used surgical instruments are available. Previous studies have reported that the bacterial load was lower than $10^{4}$ on used surgical instruments.[2-4]

The contamination may have an adverse effect on the instruments if they are not cleaned as soon as possible after use.[5] Proper cleaning prolongs the life of the instruments, keeps them in optimal condition and allows the Sterility Assurance Level (SAL) to be reached more easily by reducing the bacterial load by $3 \log _{10}$ and by shortening the time required to reach SAL.[6]

However, the direct relationship between holding time prior to cleaning and disinfection and bacterial load on contaminated instruments has not been established up to now.

Financial or Other, Competing Interest: None.

Submission 04-01-2016, Peer Review 05-02-2016,

Acceptance 12-02-2016, Published 24-02-2016.

Corresponding Author:

Mahesh Reddy $S$,

Room No. 44, IHR PG Hostel,

Krishna Hospital, Malkapur,

Karad-415110, Satara

Maharashtra.

E-mail: mahesh8487@gmail.com

DOI: $10.14260 /$ jemds $/ 2016 / 177$
In our study, we aim to determine the bacterial load on surgical instruments and to evaluate the relationship between bacterial load on stainless steel instruments and holding time prior to their cleaning.

\section{METHODS AND MATERIALS \\ Evaluation of Median Number of Bacteria on Surgical Instruments}

Forty six different instrument sets were evaluated in order to find the average bacteria per square centimeter on a used instrument. The bloodiest instrument from each set was selected. A cotton swab which was saturated with physiological saline was scrubbed on $1 \mathrm{~cm}^{2}$ of the instrument's surface. The cotton swabs were immediately put into $1 \mathrm{~mL}$ physiological saline and vortexed. Immediately after vortexing, $100 \mu \mathrm{L}$ solution from each tube was spread onto sheep blood agar. Agar plates were incubated at $37{ }^{\circ} \mathrm{C}$ for 24 hrs. and colonies were counted as colony forming units per square centimeter $\left(\mathrm{CFU} / \mathrm{cm}^{2}\right)$.

Experimental study to evaluate the relationship between Holding Time and Bacterial Load on Stainless Steel Instruments.

Three different inocula $5 \times 10^{3} \mathrm{CFU} / \mathrm{mL}$ of staphylococcus aureus ATCC 25923, Pseudomonas aeruginosa ATCC 27853 and E. coli ATCC 25922 strains were prepared in sheep blood. They were used to contaminate steam sterilized stainless steel pieces with the surface area of $10 \mathrm{~cm}^{2}$. The contaminated pieces are incubated in a sterile petri dish under room temperature. After the incubation for $2,4,6,8,12,24,36$, and $48 \mathrm{~h}$, the pieces were sonicated in physiological saline and $100 \mu \mathrm{L}$ of each solution inoculation onto sheep blood agar.

The colonies were counted and compared to time zero after overnight incubation on the basis of the time kill kinetic assays.[7] For every incubation time the tests were repeated three times and the median bacterial count of the three tests was recorded. 


\section{RESULTS}

The number of bacteria on the different instruments is shown in Table 1 . The table shows that the bacterial counts varied between 20 and $320 \mathrm{CFU} / \mathrm{cm}^{2}$, depending on the operation site. The most contaminated instruments were used in reconstructive study.

\begin{tabular}{|c|c|c|}
\hline Operating Room & $\begin{array}{l}\text { Number of } \\
\text { Instruments }\end{array}$ & $\begin{array}{c}\text { Number of } \\
\text { Bacteria } \\
\left(\mathrm{CFU} / \mathrm{cm}^{2}\right) \\
\end{array}$ \\
\hline Abdominal surgery & 14 & $2.2 \times 10^{2}$ \\
\hline Orthopedic surgery & 8 & $2.0 \times 10^{2}$ \\
\hline $\begin{array}{c}\text { Plastic } \\
\text { Reconstructive } \\
\text { surgery } \\
\end{array}$ & 7 & $3.2 \times 10^{2}$ \\
\hline $\begin{array}{c}\text { Cardiovascular } \\
\text { surgery }\end{array}$ & 5 & 70 \\
\hline Gynaecology & 4 & 20 \\
\hline Neurosurgery & 4 & 30 \\
\hline Pediatric surgery & 3 & 20 \\
\hline Biopsy instruments & 1 & No growth \\
\hline $\begin{array}{r}\text { Table 1 } \\
\text { used }\end{array}$ & $\begin{array}{l}\text { umber of bac } \\
\text { gical instrur }\end{array}$ & \\
\hline
\end{tabular}

\begin{tabular}{|c|c|c|c|}
\hline Time & $\begin{array}{c}\text { E. coli } \\
\text { ATCC 25922 }\end{array}$ & $\begin{array}{c}\text { P. aeruginosa } \\
\text { ATCC 27853 }\end{array}$ & $\begin{array}{c}\text { S. aureus } \\
\text { ATCC 25923 }\end{array}$ \\
\hline Time zero & $1 \times 10^{2}$ & $6 \times 10^{3}$ & $1.8 \times 10^{3}$ \\
\hline $2^{\text {nd }}$ hour & $4 \times 10^{2}$ & $6 \times 10^{2}$ & $3.2 \times 10^{3}$ \\
\hline $4^{\text {th }}$ hour & $4 \times 10^{2}$ & $2 \times 10^{2}$ & $1 \times 10^{3}$ \\
\hline $6^{\text {th }}$ hour & $3 \times 10^{2}$ & $4 \times 10^{2}$ & $5.4 \times 10^{3}$ \\
\hline $12^{\text {th }}$ hour & $3 \times 10^{3}$ & $6 \times 10^{3}$ & $1.6 \times 10^{4}$ \\
\hline $2^{\text {th }}$ hour & $2.3 \times 10^{6}$ & $1.5 \times 10^{6}$ & $4.2 \times 10^{6}$ \\
\hline $36^{\text {th }}$ hour & $5 \times 10^{5}$ & $3.3 \times 10^{6}$ & $1.2 \times 10^{7}$ \\
\hline $4^{\text {th }}$ hour & $1.2 \times 10^{7}$ & $2 \times 10^{6}$ & $3 \times 10^{6}$ \\
\hline \multicolumn{3}{|c|}{ Table 2: Changes in the number of bacteria overtime } \\
\hline
\end{tabular}

It was established that the bacterial load did not change during the first $6 \mathrm{~h}$., but started increasing after $6 \mathrm{~h}$. (Table 2). The bacterial count increased logarithmically and an increase in $3 \log _{10} \mathrm{CFU} / \mathrm{cm}^{2}$ was measured after $12 \mathrm{~h}$. The increase lasted for $48 \mathrm{~h}$. The logarithmic increase of the bacterial count overtime is shown in Fig. 1.

\section{DISCUSSION}

The bioburden level per instrument is dependent on the anatomic site where the device is used. Chu-Nancy et al.[2] found that the bioburden varied between 0 and $4415 \mathrm{CFU}$ per instrument after clinical use. Eighty eight percent of the instruments had a bioburden level lower than 1000. ChanMyers et al.[3] showed that bioburden level of rigid lumened medical devices after clinical use was relatively low, ranging from 10 to $10^{4} \mathrm{CFU}$ per device. Gordon smith et al.[4] established that microbial contamination on used dental handpieces varied between 42 and $250 \mathrm{CFU} / \mathrm{ml}$. Our experiments showed that bacterial load varied between 20 and $3.2 \times 10^{2}$ $\mathrm{CFU} / \mathrm{cm}^{2}$. No growth was observed in instruments in biopsy procedures. The most contaminated instruments had been in reconstructive surgery. This is due to the fact that the amount of pseudomonas in a burn wound can be as high as $10^{6} \mathrm{CFU} / \mathrm{g}$ tissue. Obviously instruments used in these interventions will be highly contaminated.[8] No growth on biopsy instruments could be observed, which can probably be explained by the short duration of the procedure.

The typical bacterial growth curve consists of four main phases. The initial stationary phase, which is also known as the lag phase starts immediately after inoculation and lasts between 2 and $3 \mathrm{~h}$. It is a period in which the cells adjust and adapt to their new environment. The duration of this phase depends on the medium, temperature and nature of the cells. The logarithmic period of growth is characterized by the exponentially increasing number of bacterial organisms overtime. It starts approximately after $4 \mathrm{~h}$ and lasts between 2 and $4 \mathrm{~h}$ depending on the nature and concentration of the nutrients in the medium, $\mathrm{pH}$ and temperature of the incubation. The logarithmic phase is followed by the stationary phase in which the number of organisms is stable.

During this phase the rate of cell dying and new ones developing is in balance. This phase may last for hours or days depending on the bacteria. With the exhaustion of nutrients, overcrowding and accumulation of toxic products in the metabolism, the culture enters the death phase. Nevertheless, a small number of cells can survive for many months due to the release of nutrients by dead cells.[9]

In the present study, it is found that the lag phase lasts $6 \mathrm{~h}$. The logarithmic phase starts after $6 \mathrm{~h}$. and lasts $18 \mathrm{~h}$. The stationary phase starts approximately after $24 \mathrm{~h}$. and ends after 48h. (Fig. 1). As instruments are not expected to be cleaned mere than $48 \mathrm{~h}$. after their use, it was not possible to establish when bacteria entered the death phase.

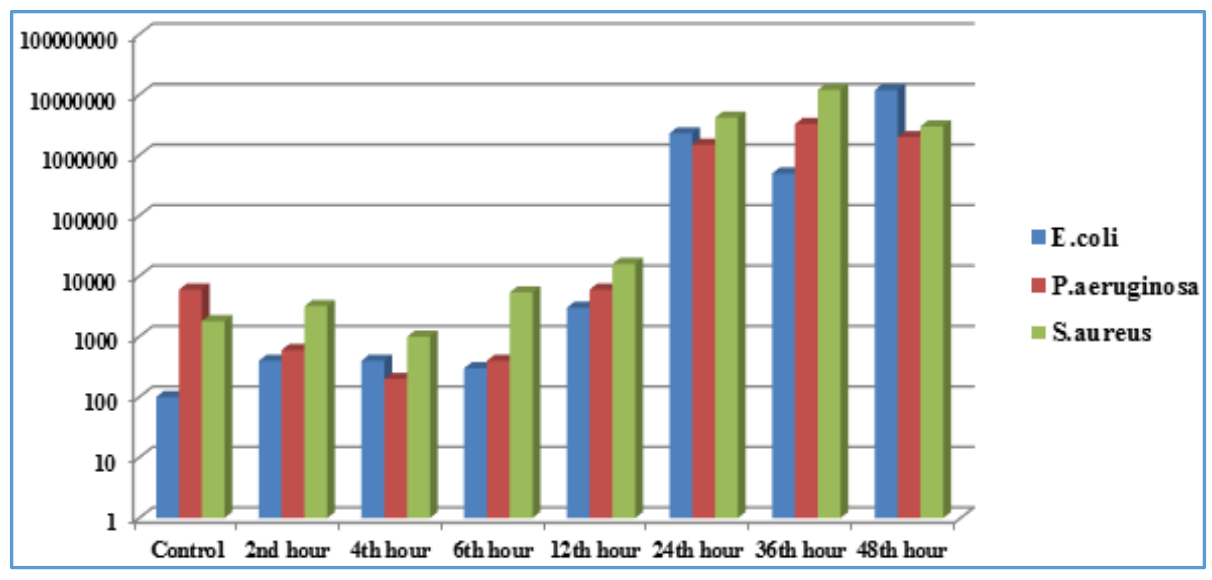

Fig. 1: Logarithmic change of bacterial load with time 
The F-value the time expressed in minutes required to reach sterility of an instrument by exposure to a certain killing agent at a certain temperature will be longer when there are large number of microorganisms on instruments before disinfection and sterilization in comparison to having just few microorganisms on instruments. The F-value is a very important parameter in determining the effectiveness of any disinfectant. It is therefore; very important to reduce the bacterial load on used instruments before the bacteria start growing.[6]

In conclusion, it has been proven that the cleaning of surgical instruments in the first $6 \mathrm{hrs}$. after use is essential in order to ensure effective disinfection and sterilization, thus to reach SAL. This reduces the bacterial load and thus decreases the infection rate in any surgeries.

\section{REFERENCES}

1. Spaulding EH, et al. Principles of microbiology as applied to operating room nursing. AORN 1963;1:49-57.

2. Chu NS, Chan-Myers H, Ghazanfari N, et al. Levels of naturally occurring microorganisms on surgical instruments after clinical use and after washing. Am J Infect Control 1999;27:315-3.

3. Chan-Myers H, McAlister D, Antonoplos P, et al. Natural bioburden levels detected on rigid lumened medical devices before and after cleaning. Am J Infect Control 1997;25:471-476.
4. Smith G, Smith A, Ramage G, et al. Assessment of biofouling of dental handpieces after use. Abstract Book of $10^{\text {th }}$ World Congress of Sterilization, Crete, Greece. 2009;(Poster no. 4):9.

5. Instrument Preparation Working Group. Proper maintenance of instruments. $8^{\text {th }}$ revised ed. Germany: Instrument Preparation Working Group 2005.

6. Huys J, et al. Sterilization of medical supplies by steam. Vol 1-General Theory, 2nd edn. Benedict Press, Germany. 2004;2:234-237.

7. Knapp C, Moody JA, et al. Time-kill assay. In: Isenberg HD (ed) Clinical microbiology procedures handbook. Vol 1. American Society for Microbiology, Washington, 1966; pp 5.16.14-5.16.20.

8. Hurst V, Sutter VL, et al. Survival of Pseudomonas aeruginosa in the hospital environment. J Infect Dis 1966;116:151-154.

9. Perkins JJ, et al. Growth and death of microorganisms. In: Perkins JJ (ed) Principles and methods of sterilization in health sciences, $2^{\text {nd }}$ edition. Charles C Thomas, Illinois, 1969;2:56-62. 